\title{
Potensi Prosesi Balimau Kasai Sebagai Atraksi Wisata Budaya Dalam Melestarikan Adat Dan Budaya Di desa Batu Belah Kecamatan Kampar Kabupaten Kampar
}

\author{
AFISI SABRI \\ $\&$ \\ LENI MARLINA \\ Dosen Sekolah Tinggi Pariwisata Riau
}

\begin{abstract}
Kampar regency has the potential of culture as a source of tourism Based on the findings, the conclusions of this study is that the potential Procession Balimau Kasai For Tourism Attractions Culture, among others, have the potential to be developed in any event to welcome the month of Ramadan. The procession potential Balimau Kasai For Tourism Attractions Culture as a cultural tourist attraction, namely: Attracting visitors or tourists; Balimau kasai a tour event as a cultural tourism attractions; and Balimau kasai a distinctive customs and culture hereditary always retained by the people in the district of Kampar. Constraints faced is the lack of coordination between all interested parties between the head region.
\end{abstract}

Keywords: Procession Balimau Kasai For Tourism Cultural Attractions

\section{PENDAHULUAN}

Kabupaten Kampar merupakan salah satu daerah yang sedang berkembang dan memiliki potensi dalam mewujudkan usaha pemerintah untuk meningkatkan ekonomi rakyat. Adapun wujud usaha pemerintah kabupaten Kampar untuk meningkatkan ekonomi masyarakat kabupaten Kampar salah satunya yaitu melalui sektor pariwisata. Untuk mengetahui lebih mendetail tentang data inventaris kepariwisataan Kampar dapat diperhatikan, diketahui bahwa peta kepariwisataan Kampar beraneka ragam, sedangkan lokasinya mayoritas di daerah Kampar. Jumlah pengunjung bervariasi setiap tahunnya, hal ini sangat dipengaruhi oleh pengetahuan pengunjung dan lokasi tempat objek tersebut.

Mulai diberlakukannya otonomi daerah oleh pemerintah pusat pada awal tahun 1998, pemda Kampar semakin gencar melakukan pembangunan di berbagai sektor, termasuk sektor pariwisata. Jika dilihat pengembangan pariwisata di kota ini, maka tampak perkembangannya cukup bagus. Hal ini membuat pemerintah daerah melalui dinas-dinas terkait dan investor bisnis pariwisata memikirkan alternatif lain di bidang pariwisata yaitu menjadikan Bangkinang dan Kampar sebagai kota wisata.

Salah satu atraksi wisata budaya yang khas secara turun temurun di kabupaten Kampar adalah mandi Balimau Kasai. Mandi "balimau bakasai" tradisi ini adalah mandi membersihkan diri di Sungai Kampar untuk menyambut bulan suci Ramadhan yang diselenggarakan sehari sebelum hari pertama puasa. Mandi Balimau diselenggarakan dalam kelompok kecil yakni keluarga dan juga secara bersama dalam bentuk kelompok masyarakat. Ini adalah sebuah tradisi yang dilakukan penduduk Melayu di Kampar yang diadakan di Sungai Batang Kampar dalam rangka menyambut bulan Ramadhan. 
Tujuannya adalah untuk mensucikan hati dan jiwa dan mempersiapkan diri untuk menyambut Ramadhan.

Pada mulanya balimau kasai menjadi upacara ritual masyarakat adat disepanjang sungai Kampar saja. Namun setelah tahun 60-an pemerintah kecamatan bahkan kabupaten telah ikut berperan mendesain upacara balimau kasai untuk tujuan promosi wisata budaya. Dibuatlah seperti perayaan yang dapat dihadiri oleh seluruh lapisan masyarakat baik dari dalam maupun dari luar daerah kampar. Mandi balimau kasai adalah membersihkan badan dalam menyambut bulan Ramadhan dengan melumuri badan dengan ramuan limau ditambah kasainya. Pada kepercayaan masyarakat adat tujuan mandi balimau kasai pada syariatnya adalah untuk membersihkan badan dari kotoran namun pada hakekeatnya didorong untuk memuliakan bulan suci Ramadhan, mandi balimau dikerjakan dengan memasang niat, membersihkan badan dan membersihkan hati/jiwa dari segala kekotoran sifat-sifat keduniawian.

Bahan ramuan liamu untuk mandi balimau adalah limau purut/nipis, kumanyang, kabelu, urat sirih koduok, lengkuas padang, serai wangi, mayang pinang, daun nilam, urat siduo, urat sibuto, urat usau, bunga kenanga, bunga tanjung, dan bunga rampai. Semua bahan ini direbus sampai kulit limau/jeruk bisa hancur saat diremas. Adapun kasai terbagi dua yaitu kasai kering dan kasai basah. Bahan ramuan kasai kering adalah beras, kencur, dan kunyit. Membuat kasai kering dengan merendam beras terlebih dahulu hingga lunak kemudian ditumbuk bersama kencur dan kunyit. Sedangkan membuat kasai basah ialah merendam beras hingga lunak kemudian ditumbuk bersama dengan kencur ditambah kumanyang dan kulit limau/jeruk. Kasai basah berwarna putih sedangkan kasai kering berwarna kuning.

Kegiatan mandi balimau kasai ini lazim dilaksanakan menyambut bulan puasa, diikuti oleh masyarakat di daerah Kampar. Berbagai atraksi kesenian dan hiburan kadangkala disiapkan di daerah pinggiran sungai untuk meramaikan tradisi ini, terlebih lagi di daerah seperti sungai Kampar yang tidak pernah ada sepi dari dilewati orang. Masyarakat daerah Kampar, Bangkinang, dan daerah lainnya berduyun-duyun mendatangi sungai Kampar untuk mengikuti prosesi tersebut. Biasanya acara tersebut dibuka oleh tetua adat, namun pada saat sekarang kegiatan ini dianggap menjadi objek pariwisata budaya. Bukan hanya masyarakat etnis Kampar (wisatawan domestik) yang ikut serta, akan tetapi juga di kunjungi oleh wisatawan dari luar Kabupaten Kampar. Diantaranya wisatawan dari Provinsi Sumatera Barat, Sumatera Utara dan beberapa kabupaten di Provinsi Riau.

Adat ini menjadi sangat menarik karena diikuti oleh seluruh lapisan masyarakat, mulai dari anak-anak, remaja sampai orang tua ikut meramaikan acara balimau kasai tersebut. Mandi Balimau Kasai, dahulunya dianggap sakral oleh orang-orang tua dahulu. Mereka mengajarkan anaknya mandi Balimau Kasai secara turun temurun hingga saat ini. Kebutuhan akan pariwisata menjadikan prosesi mandi Balimau Kasai ini sebagai salah satu hal yang sangat mungkin untuk disaksikan oleh banyak orang.

Adat ini di daerah Riau yang rata-rata diikuti oleh masyarakat Kampar sebagai tradisi yang harus tetap dilestarikan.Namun seiring perkembangan zaman yang terjadi pada saat sekarang ini, telah banyak tradisi-tradisi adat di Kabupaten Kampar yang mulai di tinggalkan terlebih di kalangan generasi muda Kampar. Mengingat perkembangan zaman, adat ini dianggap oleh para remaja dan orang dewasa sebagai media berkenalan atau mencari pasangan, dan ada juga yang berpacaran serta mandi bercampur antara laki-laki dan perempuan. Hal seperti inilah yang menjadikan prosesi 
mandi Balimau Kasai membuat kehilangan makna untuk membersihkan badan dari semua kekotoran keduniawian.

Permasalahan yang ditemui selama peneliti melakukan observasi awal adalah sesuai fenomena berikut ini: Kepariwisataan di kabupaten Kampar memiliki potensi untuk dijadikan sebagai objek wisata yang siap dikunjungi dan dipromosikan khususnya mandi Balimau Kasai. Prosesi Balimau Kasai sebagai tradisi adat dan bagian dari budaya daerah Kampar mulai kehilangan makna, terlihat acara Balimau Kasai dijadikan ajang acara muda-mudi untuk mencari pasangannya serta mandi yang bercampur antara lak-laki dan perempuan. Dari segi biaya, prosesi ini menjadi sangat murah. Bahkan tidak membutuhkan biaya sama sekali. Namun pengembangan adat ini kurang diperhatikan oleh masyarakat Kabupaten Kampar.

Sedangkan secara umum dari aspek kepariwisataan, balimau kasai menjadi hal yang sangat menarik untuk dinikmati. Balimau kasai memiliki potensi sebagai berikut : 1) Menarik minat pengunjung atau wisatawan; 2) Balimau kasai merupakan event wisata sebagai atraksi wisata budaya; 3) Balimau kasai merupakan adat dan budaya yang khas secara turun temurun selalu di pertahankan oleh masyarakat di Kabupaten Kampar.

Berdasarkan pemaparan yang telah diketengahkan secara ringkas pada latar belakang masalah tertarik melakukan kajian mengenai bagaimanakah Potensi Prosesi Balimau Kasai Sebagai Atraksi Wisata Budaya Dalam Melestarikan Adat dan Budaya Di Desa Batu Belah Kecamatan Kampar Kabupaten Kampar dengan maksud untuk mengetahui bagaimana Potensi Prosesi Balimau Kasai Sebagai Atraksi Wisata Budaya dalam Melestarikan Adat dan Budaya Desa Batu Belah Kecamatan Kampar Kabupaten Kampar, juga untuk mengetahui apa kendala-kendala yang dihadapi dan bagaimana cara mengatasi kendala tersebut dalam melestarikan Potensi Prosesi Balimau Kasai Sebagai Atraksi Wisata Budaya dan untuk mengetahui bagaimana tanggapan atau persepsi wisatawan terhadap Potensi Prosesi Balimau Kasai Sebagai Atraksi Wisata Budaya di Kabupaten Kampar.

Beberapa rujukan mengenai konsep pariwisata dijelaskan bahwa pariwisata merupakan suatu bidang usaha yang sangat kompleks karena ada banyak unsur pendukung dari industri-industri pariwisata yang terkait. Usaha pariwisata adalah usaha padat karya, menuntut kualitas tinggi, dan saling integral satu dengan yang lainnya yang bertujuan memuaskan wisatawan dengan bermacam-macam fasilitas yang mendukung, dan ditunjang dengan sumber daya manusia yang handal dari setiap pelayanan wisatawan. Menurut Oka A. Yoeti (1999:109) menginterpritasikan Pariwisata adalah salah satu perjalanan yang dilakukan untuk sementara waktu dari suatu tempat ketempat lain dengan maksud bukan untuk berusaha bisnis atau mencari ditempat nafkah dikunjunginya tetapi semata - mata untuk bersenang - senang dan mengisi waktu luang untuk menikmati perjalanan.

Pariwisata sendiri diartikan sebagai suatu perjalanan yang dilakukan orang untuk sementara waktu yang diselenggarakan dari suatu tempat ke tempat lain meninggalkan tempatnya semula dengan suatu perencanaan dan dengan maksud bukan untuk berusaha atau mencari nafkah ditempat yang dikunjunginya, tetapi semata-mata untuk menikmati kegiatan pertamasyaan dan rekreasi atau untuk memenuhi keinginan yang beraneka ragam (Sihite, 2000 : 47). Perpindahan orang untuk sementara ke suatu tujuan diluar tempat tinggal maupun tempat kerjanya yang biasa, serta aktivitas yang dilakukannya 
selama tinggal ditempat tujuan tersebut, dan kemudahan-kemudahan yang disediakan untuk memenuhi kebutuhannya adalah bagian dari pariwisata.

Adapun jenis - jenis dari pariwisata menurut Samsuridjal (1997 : 24) adalah sebagai berikut : wisata budaya, wisata kesehatan, wisata olah raga, wisata komersial, wisata industri, wisata politik, wisata konvensi, wisata sosial, wisata pertanian, wisata maritim atau bahari, wisata cagar alam, wisata buru, wisata pilgrim dan wisata bulan madu. Kemudian berkaitan dengan atraksi wisaya dijelaskan wisata diartikan sebagai bentuk sebuah perjalanan yang direncanakan disusun oleh perusahaan perjalanan dengan waktu seefektif mungkin dengan menggunakan fasilitas-fasilitas pendukung wisata lain, guna membuat peserta tour merasa senang dan puas (Kesrul, 2003:3). Menurut UU nomor 9 tahun 1990 tentang kepariwisataan wisata didefinisikan sebagai kegiatan perjalanan yang dilakukan secara sukarela dan bersifat sementara, serta perjalanan itu sebagian atau seluruhnya bertujuan untuk menikmati objek dan daya tarik wisata.

Atraksi wisata adalah sesuatu yang dapat dihubungkan dengan pertunjukan atau suatu tampilan yang menyertakan sumber daya manusia sebagai hal yang paling utama. Hal ini juga dinyatakan dalam kamus Besar Bahasa Indonesia karangan Hasan Alwi (2005:112) bahwa atraksi wisata adalah suatu pertujukan wisata. Di samping itu diperlukan juga suatu keterampilan dari manusia itu sendiri dalam melakukan pertujukan yang akan ditampilkan. Bagian penting lainnya adalah persiapan. Jenis atraksi wisata yang ada di Indonesia adalah: tari-tarian, kesenian rakyat tradisional, dan upacara adat.

Motif-motif dari tourist interest, yang berupa perwujudan konkrit dari keinginan-keinginan, dapat diklasifikasikan sebagai berikut : motif perjalanan untuk menikmati atraksi-atraksi wisata. Istilah pariwisata budaya memiliki beberapa definisi. Dalam sebuah buku yang dikarang oleh Valene Smith membedakan antara pariwisata etnik dan pariwisata budaya: pariwisata etnik dipasarkan untuk umum/wisatawan berdasarkan budaya yang mengalir/turun temurun dari penduduk pribumi yang bersifat eksotis. Lebih lanjut Valene Smith mendefinisikan pariwisata etnik dengan memfokuskan pada orang-orang yang meninggalkan identitas budaya yang keunikannya dipasarkan kepada wisatawan (http://wikimediafoundation.org/).

Menurut Oka A. Yoeti (2006:27) mengenai wisata budaya diartikan sebagai jenis kegiatan pariwisata yang objeknya adalah kebudayaan. Ini dibedakan dari minatminat khusus lain, seperti wisata alam dan wisata petualangan. Objek daya tarik wisata budaya itu dapat berkisar pada beberapa hal, seperti kesnian (seni rupa dan segala bentuk seni pertunjukan), tata busana, boga, upacara adat, demonstrasi kekebalan dan komunikasi dengan alam gaib, lingkungan binaan, serta keterampilan khusus fungsional seperti membuat alat-alat.

Ada 12 unsur kebudayaan yang dapat menarik kedatangan wisatawan, yaitu: Bahasa (language); Masyarakat (traditions); Kerajinan tangan (handicraft); Makanan dan kebiasaan makan (foods and eating habits); Musik dan kesenian (art and music); Sejarah suatu tempat (history of the region); Cara Kerja dan Teknolgi (work and technology); Agama (religion) yang dinyatakan dalam cerita atau sesuatu yang dapat disaksikan; Bentuk dan karakteristik arsitektur di masing-masing daerah tujuan wisata (architectural characteristic in the area); Tata cara berpakaian penduduk setempat (dress and clothes); Sistem pendidikan (educational system); dan aktivitas pada waktu senggang (leisure activities). 
Di Desa Batu Belah Kabupaten Kampar terdapat suatu tradisi budaya yang disebut Balimau Kasai. Balimau Kasai merupakan acara adat yang mengandung nilai sakral yang khas. Balimau Kasai adalah sebuah upacara tradisional yang istimewa bagi masyarakat Kampar di Propinsi Riau untuk menyambut bulan suci Ramadhan. Acara ini biasanya dilaksanakan sehari menjelang masuknya bulan puasa. Upacara tradisional ini selain sebagai ungkapan rasa syukur dan kegembiraan memasuki bulan puasa, juga merupakan simbol penyucian dan pembersihan diri. Balimau sendiri bermakna mandi dengan menggunakan air yang dicampur jeruk yang oleh masyarakat setempat disebut limau. Jeruk yang biasa digunakan adalah jeruk purut, jeruk nipis, dan jeruk kapas. Sedangkan kasai adalah wangi-wangian yang dipakai saat berkeramas. Bagi masyarakat Kampar, pengharum rambut ini (kasai) dipercayai dapat mengusir segala macam rasa dengki yang ada dalam kepala, sebelum memasuki bulan puasa.

Tradisi Balimau Kasai di Kampar, konon, telah berlangsung berabad-abad lamanya sejak daerah ini masih di bawah kekuasaan kerajaan. Upacara untuk menyambut kedatangan bulan Ramadhan ini dipercayai bermula dari kebiasaan Raja Pelalawan. Namun ada juga anggapan lain yang mengatakan bahwa upacara tradisional ini berasal dari Sumatera Barat. Bagi masyarakat Kampar sendiri upacara Balimau Kasai dianggap sebagai tradisi campuran Hindu-Islam yang telah ada sejak Kerajaan Muara Takus berkuasa.

Menurut Gamal Suwantoro (1997:48-49) produk wisata adalah keseluruhan pelayanan yang diperoleh dan dirasakan atau dinikmati wisatawan semenjak ia meninggalkan tempat tinggalnya sampai ke daerah tujuan wisata yang telah dipilih nya dan kembali kerumah dimana ia berangkat semula. Produk wisata juga merupakan gabungan dari beberapa komponen, antara lain : Atraksi Suatu Daerah Tujuan Wisata; Fasilitas yang tersedia; dan Aksesbilitas ke dan dari tujuan wisata.

Menurut R.S. Darmardjati (2001: 35-36) Dinas Pariwisata Daerah (DIPARDA), merupakan aparat atau instansi kelengkapan dalam struktur Pemerintah Tingkat I dan II, yang dibentuk dan ditugaskan untuk menangani dan mengelola segi-segi administrasi, serta merupakan badan pelaksana dan eksekutif untuk kebijaksanaan pemerintah daerah yang menyangkut pengembangan, pengelolaan dan pengaturan soal-soal kepariwisataan di daerah bersangkutan. Kebijaksanaan dan administrasi operasional ini tentu saja tetap mengacu kepada kebijaksanaan dan ketentuan-ketentuan/peraturan-peraturan yang telah ditetapkan dan digariskan dari pusat maupun tingkat nasional. Masalah-masalah yang ditangani termasuk pembinaan sumber daya manusia, peningkatan profesionalisme pelayanan dan mutu fasilitas wisata (hotel, biro perjalanan, transportasi, restoran, sajian kesenian, dan hiburan, produk cenderamata, dan sebagainya) serta menggali kekayaan objek wisata setempat dan mengembangkannya.

Menurut Nyoman S. Pendit (1986:135) kebijakan kepariwisataan dapat dirumuskan sebagai berikut: "segala sesuatu tindakan instansi Pemerintah dan badan/organisasi masyarakat yang mempengaruhi kehidupan kepariwisataan itu sendiri." Menurut Peraturan Daerah Propinsi Riau Nomor 4 Tahun 2004 tentang Rencana Induk Pengembangan Pariwisata disebutkan bahwa potensi objek dan daya tarik wisata dibagi menjadi 3 (tiga) bagian, yaitu : Potensi objek dan daya tarik wisata budaya terdiri dari peninggalan budaya, adat istiadat daerah, musik tradisional, hasil karya seni suara, tari, lukis, pahat yang dapat memberikan daya tarik wisatawan. Potensi objek dan daya tarik wisata alam terdiri dari segala keindahan alam meliputi gunung, hutan, pantai, gua, dan panorama yang lain. Potensi objek dan daya tarik wisata minat 
khusus terdiri dari segala sesuatu yang dapat menarik wisatawan berkunjung ke suatu tempat.

Rencana perjalanan yang disusun oleh perusahaan perjalanan juga disebut paket wisata. Menurut M A. Desky (2001 : 23) Paket wisata merupakan perpaduan beberapa produk wisata, minimal dua pokok yang dikemas menjadi satu kesatuan harga yang tidak dapat dipisahkan satu sama lain. Selanjutnya menurut Happy Marpaung, (2002:13) wisatawan adalah orang yang mengadakan perjalanan dari tempat kediamannya tanpa menetap ditempat yang didatanginya, atau hanya untuk sementara waktu tinggal yang didatanginya.

Adat adalah aturan dan perbuatan yang lazim dituruti atau dilakukan sejak dahulu kala (Kamus umum bahasa Indonesia). Timbulnya adat berawal dari usaha orang-orang dalam suatu masyarakat di daerah yang menginginkan terciptanya ketertiban di masyarakat. Adat istiadat adalah tata kelakuan yang kekal dan turun temurun dari generasi ke generasi sebagai warisan sehingga kuat hubungan dan penyatuannya dengan pola - pola perilaku masyarakat.

Adat Istiadat adalah aneka kelaziman dalam suatu nagari yang mengikuti pasang naik dan pasang surut situasi masyarakat. Kelaziman ini pada umumnya menyangkut pengejawatahan unjuk rasa seni budaya masyarakat, seperti acara-acara keramaian anak nagari, seperti pertunjukan randai, saluang, rabab, tari-tarian dan aneka kesenian yang dihubungkan dengan upacara perhelatan perkawinan, pengangkatan penghulu maupun untuk menghormati kedatangan tamu agung.

Jadi Adat istiadat dalam kehidupan masyarakat dapat diartikan sebagai berikut: Sekelompok orang yang hidup dengan tradisi dan budaya - budaya tertentu, adat istiadat yang sudah ada sebelumnya, yang tidak terpengaruhi oleh perubahan zaman karena mereka merasa cukup dengan kehidupan dan penghidupan yang mereka jalani secepat apapun evolusi kebudayaan pada masa tersebut. Masyarakat yang kehidupannya masih dipegang teguh oleh adat istiadat lama yang mereka miliki. Yang dimaksut adat istiadat disini adalah adanya suatu aturan baku mencangkup segala konsep budaya yang di dalamnya terdapat aturan terhadap tingkah laku dan perbuatan manusia dalam menjalani kehidupan.

Dalam mencari tempat-tempat rekreasi yang berpotensi untuk bersenangsenang ada kecenderungan negara-negara berkembang untuk menjadikan even adat, cahaya matahati dan laut sebagai daya tarik untuk daerah tujuan wisata. Dengan cara demikian pembangunan kepariwisataan menjadi sesuatu yang mudah untuk pembangunan perekonomian, yaitu hanya mengeksploitasikan keindahan alam untuk mengatasi kesukaran dalam defisit neraca pembayaran yang dialami. Ada orang beranggapan, pengembangan kepariwisataan seakan-akan dapat memberi hadiah dengan mudah. Sering terjadi negara-negara berkembang mengharapkan hasil yang banyak dari industri pariwisata yang dikembangkan tetapi menghadapi beberapa masalah dalam penggarapannya (Oka A. Yoeti, 2000: 6).

Tidak hanya perusahaan-perusahaan yang dapat menyediakan kamar untuk menginap, makanan dan minuman (bar dan restoran), perencana perjalanan wisata (tour operator), agen perjalanan (travel agent), industri kerajinan, pramuswisata (guide) tenaga terampil, dan lain sebagainya. Tetapi industri pariwisata yang memiliki potensi juga memerlukan prasarana ekonomi, seperti jalan raya, jembatan, terminal, pelabuhan, lapangan udara. Di samping itu dibutuhkan pula prasarana yang bersifat public utilities, seperti pembangkit listrik dan telekomunikasi, bank, money changer, perusahaan 
asuransi, advertising agent, percetakan dan sektor perekonomian lainnya (Oka A. Yoeti, 2000: 3).

Masyarakat Ekowisata Indonesia (MEI) memberi kriteria pemilihan lokasi sebagai berikut (Oka A. Yoeti, 2000: 3): Daerah itu harus memiliki keunikan yang khusus dan tidak terdapat di tempat lain, seperti kepulauan Nias, Pagai atau Enggano yang memiliki etnis berbeda dengan suku bangsa lainnya di Indonesia. Memiliki atraksi seni budaya yang unik dan bebeda dengan suku bangsa lainnya, seperti Badui, Tengger, Toraja, Dayak, Kubu, atau Sakai. Adanya kesiapan masyarakat setempat untuk berpartisipasi dalam proyek yang akan dibangun. Perizinan kawasan tidak meragukan. Tersedia sarana akomodasi, rumah makan, dan sarana pendukung lainnya. Tersedia asebilitas yang memadai dan dapat membawa wisatawan dari dan ke kawasan yang akan dikembangkan (berpotensi).

\section{METODE}

Penelitian ini dilakukan di Desa Batu Belah Kecamatan Kampar Kabupaten Kampar dan pada saat ada even kegiatan mandi Balimau Kasai. Populasi dalam penelitian ini adalah instansi yang terkait yaitu Staff Desa Batu Belah Kecamatan Kampar Kabupaten Kampar, masyarakat pengunjung Balimau Kasai dan pihak yang terkait (Ninik Mamak) serta Dinas Pariwisata dan Kebudayaan Kabupaten Kampar. Dalam analisa data ini, penulis mengenakan metode deskriptif observatif yaitu suatu cara menganalisa data yang sudah ada yang dihubungkan dengan keadaan yang sebenarnya serta dirangkai dengan teori-teori yang mendukung pembahasan masalah tersebut.

\section{HASIL}

\section{Potensi Prosesi Balimau Kasai}

Dalam mencari tempat-tempat rekreasi yang berpotensi untuk bersenang-senang ada kecenderungan wisatawan untuk menjadikan wisata budaya sebagai salah satu kesenangan tersendiri di samping cahaya matahari dan laut sebagai daya tarik untuk daerah tujuan wisata. Dengan cara demikian pembangunan kepariwisataan menjadi sesuatu yang mudah untuk pembangunan perekonomian, yaitu tidak hanya mengeksploitasikan keindahan alam untuk mengatasi kesukaran dalam defisit neraca pembayaran yang dialami.

Pembangunan event budaya merupakan bagian pengembangan. Secara garis besar pada tahap operasional terdapat pekerjaan yang mesti dicermati yakni penanganan pengunjung dan pemeliharaan fasilitas termasuk lingkungan sekitarnya. Dampak dari kegaitan ini adalah memberikan kenyamanan pada wisatawan serta kelanjutannya untuk waktu yang lama dan memberikan keuntungan bagi seluruh masyarakat.

Adapun potensi prosesi Balimau Kasai sebagai atraksi wisata budaya adalah sebagai berikut:

1. Menarik minat pengunjung/wisatawan

Kabupaten Kampar merupakan salah satu daerah yang memiliki daya tarik wisata yang menarik. Upaya pemerintah daerah melalui Dinas Pariwisata dan Kebudayaan dalam meningkatkan kunjungan wisatawan harus benar-benar di laksanakan dengan baik, mengingat bahwa Kabupaten Kampar memiliki potensi 
mendatangkan minat wisatawan untuk berkunjung. Balimau kasai merupakan wisata budaya yang ada di Kabupaten Kampar yang berpotensi mendatangkan wisatawan. Balimau kasai di hadiri oleh seluruh lapisan masyarakat, mulai dari anak-anak, remaja dan orang dewasa. Balimau kasai juga di hadiri oleh masyarakat dari daerah-daerah maupun provinsi di luar Kabupaten Kampar.

2. Balimau kasai merupakan event wisata sebagai atraksi wisata budaya.

Balimau Kasai tradisi mandi membersihkan diri di Sungai Kampar untuk menyambut bulan suci Ramadhan. Ini merupakan tradisi yang dilakukan penduduk Melayu di Kampar yang diadakan di Sungai Kampar dalam rangka menyambut bulan Ramadhan. Prosesi Balimau Kasai Sebagai Atraksi Wisata Budaya antara lain memiliki potensi untuk lebih dikembangkan dalam acara setiap menyambut bulan Ramadhan.

3. Balimau kasai merupakan adat dan budaya yang khas secara turun temurun yang selalu di pertahankan oleh masyarakat di Kabupaten Kampar. Acara Prosesi Balimau Kasai yang dianggap sudah menjadi adat kebiasaan dari zaman dahulu. Tradisi Balimau Kasai di Kampar, konon, telah berlangsung berabad-abad lamanya sejak daerah ini masih di bawah kekuasaan kerajaan. Upacara untuk menyambut kedatangan bulan Ramadhan ini dipercayai bermula dari kebiasaan Raja Pelalawan. Namun ada juga anggapan lain yang mengatakan bahwa upacara tradisional ini berasal dari Sumatera Barat. Bagi masyarakat Kampar sendiri upacara Balimau Kasai dianggap sebagai tradisi campuran Hindu-Islam yang telah ada sejak Kerajaan Muara Takus berkuasa. Walaupun ada anggapan yang berbeda tentang Prosesi Balimau Kasai tapi masyarakat di Kabupaten Kampar tetap mempertahankan tradisi Balimau Kasai tersebut.

\section{Kendala-kendala dan Cara mengatasi kendala-kendala dalam upaya melestarikan Prosesi Balimau Kasai Sebagai Atraksi Wisata Budaya}

Dalam mengembangkan objek wisata khususnya wisata budaya yaitu pelaksanaan Prosesi Balimau Kasai sebagai daya tarik wisata budaya dalam melestarikan adat dan budaya di Kabupaten Kampar tidak semua aktivitas dapat terlaksana dengan baik, tentu banyak hal yang menjadi kendala.

Permasalahan yang paling sering dihadapi dalam menjadikan Prosesi Balimau Kasai Sebagai Atraksi Wisata Budaya dalam melestarikan adat dan budaya Kabupaten Kampar adalah:

a. Kurangnya koordinasi antara semua pihak yang berkepentingan sehingga sulit dilakukan usaha penggalian lebih mendalam tentang Prosesi Balimau Kasai Sebagai Atraksi Wisata Budaya ini, yang diakibatkan di antaranya adalah kurangnya kerjasama dengan masyarakat. Kurangnya kesadaran akan pelestarian budaya sebagai potensi wisata. Contohnya, kurang sosialisasi budaya oleh pemerintah dan pelaku budaya, kurangnya minat kalangan muda untuk mempelajari budaya asli Kampar, kurangnya program serta aktivitas kebudayaan oleh pemerintah dan lembaga adat Kampar, kurangnya apresiasi kepada para pelaku budaya. Adapun semua pihak yang berkepentingan adalah kepala daerah, kepala dinas pariwisata beserta jajaran dan staf, para petinggi-petinggi adat dalam hal ini adalah ninik mamak serta masyarakat selaku pelaku dan pemilik Prosesi Balimau Kasai. 
b. Pengangkatan pelaksanaan Prosesi Balimau Kasai di Kabupaten Kampar di pentas budaya, dimana masyarakat dianggap kurang menyadari betul pentingnya nilai estetika. Prosesi Balimau Kasai Sebagai Atraksi Wisata Budaya ini sering dijadikan sarana memadu Asmara bagi para muda mudi dan menjadikan prosesi ini kurang bermakna religius.

c. Mandi-mandi bercampur. Dalam proses Balimau Kasai sering terjadi aktivitas mandi bersama, walaupun tidak secara intim akan tetapi dapat diperhatikan tata cara yang dilarang oleh adat maupun budaya. Seharusnya prosesi mandi Balimau Kasai dilaksanakan secara terpisah antara laki-laki dan perempuan.

Agar permasalahan yang ditemui tersebut dapat diatasi, maka khususnya dinas dan masyarakat dapat melakukan upaya untuk mengatasi hambatan di atas, antara lain adalah sebagai berikut:

a) Melakukan koordinasi. Yaitu melakukan teknik penyusunan kembali seluk beluk Prosesi Balimau Kasai Sebagai Atraksi Wisata Budaya sehingga diketahui dengan jelas seperti apa Prosesi Balimau Kasai Sebagai Atraksi Wisata Budaya di Desa Batu Belah Kecamatan Kampar Kabupaten Kampar tersebut, dalam hal ini adalah koordinasi antar semua pihak yang berkepentingan, terutama para petinggi-petinggi adat dalam hal ini adalah para pucuk-pucuk adat dan Ninik Mamak (Kepala Persukuan).

b) Pembinaan. Agar dapat melaksanakan Prosesi Balimau Kasai Sebagai Atraksi Wisata Budaya dengan baik perlu adanya pembinaan. Pembinaan bisa dilakukan oleh masyarakat, selain itu juga melibatkan para tetua adat yang benar-benar memahami Prosesi Balimau Kasai di Kabupaten Kampar ini. Sehingga Prosesi Balimau Kasai Sebagai Atraksi Wisata Budaya juga tidak kehilangan makna dan tidak dijadikan sarana bagi muda mudi untuk saling berkenalan atau mencari pasangan.

c) Promosi. Untuk mengatasi permasalahan yang dianggap bisa menjadikan Prosesi Balimau Kasai Sebagai Atraksi Wisata Budaya ini dikenal dan memiliki potensi adalah dengan cara memasarkannya, baik melalui media, radio, paket wisata maupun brosur dan majalah lokal dan nasional khususnya menjelang puasa.

\section{SIMPULAN}

Berdasarkan hasil penelitian, maka kesimpulan penelitian ini adalah bahwa potensi Prosesi Balimau Kasai Sebagai Atraksi Wisata Budaya antara lain memiliki potensi untuk lebih dikembangkan dalam acara setiap menyambut bulan Ramadhan. Adapun potensi Prosesi Balimau Kasai Sebagai Atraksi Wisata Budaya sebagai daya tarik wisata budaya yaitu: Menarik minat pengunjung atau wisatawan; Balimau kasai merupakan event wisata sebagai atraksi wisata budaya; dan Balimau kasai merupakan adat dan budaya yang khas secara turun temurun selalu di pertahankan oleh masyarakat di Kabupaten Kampar.

Setiap pekerjaan yang dilakukan akan memiliki kendala-kendala yang tidak dapat dihindari demikian juga dengan apa yang dilakukan oleh pemerintah Kabupaten Kampar. Kendala-kendala yang dihadapi Desa Batu Belah Kecamatan Kampar Kabupaten Kampar dalam upaya mempromosikan Prosesi Balimau Kasai Sebagai Atraksi Wisata Budaya antara lain: kurangnya koordinasi antara semua pihak yang 
berkepentingan antara kepala daerah, kepala dinas pariwisata dan staff serta para ninik mamak dan masyarakat sebagai pelaku Prosesi Balimau Kasai. pengangkatan pelaksanaan Prosesi Balimau Kasai di Kabupaten Kampar di pentas budaya, dimana masyarakat dianggap kurang menyadari betul pentingnya nilai estetika. Prosesi Balimau Kasai Sebagai Atraksi Wisata Budaya ini sering dijadikan sarana memadu Asmara bagi para muda mudi dan menjadikan prosesi ini kurang bermakna religius. Dalam proses Balimau Kasai sering terjadi aktivitas mandi bercampur antara laki-laki dan perempuan

Adapun cara mengatasi kendala-kendala dalam melestarikan Prosesi Balimau Kasai sebagai atraksi wisata budaya antara lain : Melakukan koordinasi. Yaitu melakukan teknik penyusunan kembali seluk beluk Prosesi Balimau Kasai Sebagai Atraksi Wisata Budaya sehingga diketahui dengan jelas seperti apa Prosesi Balimau Kasai Sebagai Atraksi Wisata Budaya. Pembinaan. Agar dapat melaksanakan Prosesi Balimau Kasai Sebagai Atraksi Wisata Budaya dengan baik perlu adanya pembinaan. Pembinaan bisa dilakukan oleh masyarakat, selain itu juga melibatkan para tetua adat yang benar-benar memahami Prosesi Balimau Kasai. Promosi. baik melalui media, radio, paket wisata maupun brosur dan majalah lokal dan nasional khususnya menjelang puasa.

\section{DAFTAR PUSTAKA}

Damardjati, R.S, 2001. Istilah-Istilah Dalam Pariwisata, Pradnya Paramitha, jakarta.

Desky, M. A, 2001. Pengantar Bisnis Biro Perjalanan Wisata, Adi Citra Karya Nusa, Yogyakarta.

, 2001. Manajemen Perjalanan Wisata, Adi Citra Karya Nusa, Yogyakarta.

Direktorat Jendral Pariwisata di dalam Ketetapan MPR No. II/MPR/1983 tentang GBHN.

Gamal Suwantoro. 1997. Dasar-dasar Pariwisata, Penerbit Andi, Yogyakarta.

Hasan Alwi, 2005. Kamus Besar Bahasa Indonesia, Balai Pustaka, jakarta.

http://raiutama.blogdetik.com/index.php/bisnis/pariwisata/.

http://wikimediafoundation.org/.

Mardimin, 1994. Kamus Besar Bahasa Indonesia, Balai Pustaka, jakarta.

Marpaung, Happy, 2002. Pengetahuan Kepariwisataan, Alfabeta, Yogyakarta.

M, Kesrul, 2003. Penyelenggaraan Operasi Perjalanan Wisata, PT. Grasindo, Jakarta.

Pendit Nyoman S, 2002. Ilmu Pariwisata, Pradnya Paramitha, Jakarta. 
Peraturan Daerah Propinsi Riau Nomor 4 Tahun, 2004. Pengembangan Pariwisata, Pekanbaru.

Riduwan, 2009. Belajar Mudah Penelitian untuk Guru-Karyawan dan Peneliti Pemula, Alfabeta. Bandung.

, 2010. Skala-Skala Pengukuran Variabel-Variabel Penelitian, Alfabeta. Bandung.

Sihite, 2002. Pariwisata dan Komponennya, Rajawali Pers, Jakarta.

Soentoro, Ali Idris, 2003. Cara Mudah Belajar Metodologi Penelitian Bisnis, CV Taramedia, Depok.

Syamsuridjal, 1997. Peluang di Bidang Pariwisata, Mutiara Sumber Widya. Jakarta.

Sugiyono, 2005, Metode Penelitian Adiministrasi, Alfabeta, Bandung.

UU Nomor 9, 1990. Kepariwisataan.

Wardiyanta. 2006. Metode Penelitian Pariwisata, Andi, Yogyakarta.

Yoeti, Oka A, 1999, Guiding System, Angkasa, Bandung. 2000, Pengantar Pariwisata, Gramedia Pustaka Utama, Jakarta. 2006, Pariwisata Budaya, Gramedia Pustaka Utama, Jakarta. 